\title{
ЕМПАТІЯ У ПРОФЕСІЙНІЙ ДІЯЛЬНОСТІ МЕДИЧНИХ СЕСТЕР
}

\author{
Т. В. Павлюк, Т. І. Толокова
}

\author{
Комунальний заклад «Рівненська обласна клінічна лікарня» Рівненської обласної ради \\ ДВНЗ «Тернопільський державний медичний університет \\ імені І. Я. Горбачевського МОЗ Украӥни»
}

У статті наведено основні напрямки досліджень емпатії в медсестринській діяльності. Розглянуто емпатію як важливу якість у роботі медичної сестри. Аргументовано проблему емпатії як стабільної особистісної характеристики медсестри. Досліджено аспекти емпатійної комунікації медсестер.

\section{EMPATHY IN PROFESSIONAL ACTIVITY OF NURSES}

\author{
T. V. Pavlyuk, T. I. Tolokova \\ Municipal Institution «Rivne Regional Clinical Hospital» Rivne Regional Council \\ I. Horbachevsky Ternopil State Medical University
}

The article presents main directions of empathy research in nursing practice. Empathy is considered as an important quality of work of a nurse. The problem of empathy as a stable personality characteristic of the nurse is substantiated. The aspects of empathy communication of nurses are investigated.

Вступ. Трансформаційні зміни в сучасному українському суспільстві стосуються усіх сфер, зокрема й галузі охорони здоров'я, яка, водночас, є відображенням економічного і політичного стану країни. Підвищення якості медичної допомоги населенню вимагає концентрації професійних зусиль усіх медпрацівників. Однез найважливіших місць відводиться медичним сестрам. Адже виконання ними відповідальної роботи безпосереднього догляду за пацієнтами - здійснюється в умовах значного психофізичного навантаження. Це актуалізує необхідність урахування характеру професійно-особистісних характеристик медичної сестри, від сформованості яких залежить рівень надання якісної медичної допомоги. Сфера психологічної підготовленості медичної сестри тісно пов'язана $з$ емоційно-ціннісними чинниками інтерперсональної взаємодії з пацієнтами за допомогою комунікативного арсеналу психотерапевтичного впливу, вербальної та невербальної підтримки.

Встановлення «контакту», взаємин із пацієнтами містить елементи психотерапевтичної роботи, де емпатії відводиться особливе місце, адже завдяки їй стає можливим осягнення неповторності та унікальності переживань і думок іншої людини. Делікатність, тактовність іувага - базові принципи дотримання про- фесійності в роботі медичної сестри. Емпатія $є$ вищим рівнем комунікативно-деонтологічних умінь взаємодії з пацієнтами, а тому відображає інтегративну професійну властивість медичної сестри [1].

Проблема емпатії медичних сестер частково розглядається в сфері медичної психології в таких контекстах: психології взаємодії лікаря і пацієнта (М. Кабанов, Б. Карвасарський, М. Лебединський, С. Лібіх, В. Матвєєв та ін.); психології та етики взаємин медичних працівників та пацієнтів, здійснення деонтологічного впливу (Ю. Віленський, О. Грандо, Н. Магазанник, В. Менделевич та ін.); відображення особливостей професійної діяльності медичних працівників та соціально-психологічних чинників їі ефективності (І. Вітенко, М. Жукова, Л. Коробка, О. Юдіна та ін.); урахування психологічних особливостей професіоналізації медичних сестер (Л. Бурлачук, І. Вітенко, І. Харді та ін.). Зростання ролі фахівців сестринської справи як активних виконавців лікувальних процедур у медико-профілактичній діяльності стимулює пошук нових підходів щодо оцінки рівня розвитку у них особистісних комунікативних компетентностей. Однак поза межами наукового теоретичного та емпіричного обґрунтування залишилась особистість медичної сестри з індивідуальними властивостями їі емоційного реагування на значущі професійні ситуації, серед яких 
найважливіше місце посідають емпатія та емпатійні здібності, наявність навичок встановлення адекватних та емоційно-сприятливих взаємин із пацієнтами, вміння аналізувати власну поведінку і поведінку оточуючих, етичність, наявність глибокої інтуїції тощо.

Основна частина. Мистецтво сестринської справи полягає в гармонійному поєднанні професійних компетенцій і спілкування у процесі догляду за пацієнтами, в умінні захистити пацієнта від його власних хвилювань, негативних думок і почуттів, які істотно сповільнюють процес одужання. Професійна діяльність медичної сестри відбувається в системі «людина - людина», тому потребує від фахівців сестринської справи розуміння переживань і почуттів пацієнтів. У взаємодії медичної сестри і пацієнта відбувається вияв особистісних характеристик, найзначущішою з яких є емпатія. Цей феномен роботі медичної сестри передбачає чуйне ставлення до іншої людини, прийняття особистості пацієнта в цілісності, вияв власної емоційної нейтральності, відсутність оціночних суджень щодо пацієнта [2]. Емпатія $\epsilon$ динамічним і процесуальним психічним процесом, а їі функціонування визначається цінностями і мотиваційними установками медичної сестри.

Ідея особистісної взаємодії в процесі терапії не нова і бере свій початок із давньогрецької традиції Гіппократа, який сформулював основні тези лікарської позиції. Вони не втратили своєї актуальності й нині в роботі фахівців сестринської справи: «natura sanat, medicus curat morbo» («лікує хвороби лікар, але виліковує природа»), «primum non nocere» («перш за все не нашкодити»), «qui bene interrogat, bene dignoscit; qui bene dignoscit, bene curat» («хто добре розпитує - добре ставить діагноз; хто добре ставить діагноз - добре лікує») [3].

Незважаючи на вдосконалення інструментальних методів діагностики і тенденцію до мінімізації міжособистісної взаємодії медичних працівників із пацієнтом, у сучасній медицині незмінним залишається постулат про важливість емпатичного контакту з пацієнтом. Це зумовлено тим, що неадекватна комунікація медсестри з пацієнтом без належного співчуття спричиняє зміну фахівців, соматизацію пацієнтів, агравацію соматичних симптомів [4], тобто процес реабілітації перетворюється на перманентну діагностику і частішу госпіталізацію. Подібна тенденція позначена західними вченими як «doctor shopping» [5].

Емпатія $є$ невід'ємною частиною позитивного мислення (оптимізму) медсестри, в якому відбувається пошук і надання особливого, основаного на співчутті, способу отримання, обробки і перевірки достовірності інформації, отриманої від пацієнта. 3бір і аналіз інформації здійснюються двома способами: мотивуючи пацієнта на отримання будь-якої інформації для посилення власної залученості до процесу спілкування, або ж діючи в якості зворотнього зв'язку на вже зібрану інформацію. Визначення емпатії як властивості особистості надаєїй статус чинника, який $\epsilon$ постійно діючим фактором виникнення ситуацій утрудненого спілкування та виходу з них. Таке трактування емпатії робить акцент на їі ролі як механізму міжособистісного спілкування, вказує на двосторонні зв'язки суб'єктів емпатії.

Враховуючи це, в межах дослідження актуалізується розгляд деталізованої схеми класифікації характерних ознак взаємодії в діаді «медична сестра і пацієнт». Зазвичай пацієнти схильні приховувати свій емоційних стан, досить часто натякають про нього, однак не висловлюють його безпосередньо. Якщо медичний працівник ігнорує натяк і переводить розмову в біомедичну парадигму, то пацієнт повертається до своєї проблеми знову і знову. Існує кілька ознак виявлення пацієнтами власного емоційного стану та реакції на нього медсестер:

1) «потенційна емпатійна можливість» - висловлювання пацієнта, в якому наявний прихований натяк на емоцію;

2) «емпатійна можливість» - пряме виявлення емоції пацієнтом;

3) «емпатійна відповідь» - демонстрація розпізнавання медсестрою виявленої пацієнтом емоції;

4) «розвиток потенційної емпатійної можливості» адекватна реакція медичної сестри на виявлену емоцію пацієнта та його спрямування на відкрите виявлення (наприклад, за допомогою прямого запитання «l як Ви себе почуваєте в таких умовах?»);

5) «втрата емпатійної можливості» - репліка медсестри або неадекватна реакція на виявлену пацієнтом емоцію, яка формується залежно від емоційного стану пацієнта [6];

6) «обрив потенційної емпатійної можливості» - висловлювання медсестри, яке не дає змоги пацієнтові відкрито висловити емоцію.

Адекватна реакція медсестри на всі «емпатичні можливості» здатна торкнутися повного спектра психоемоційного стану пацієнта. На думку В. Зін (W. Zinn), це $\epsilon$ «ефектом ласо», оскільки на момент лікування пацієнти сприймають медичну сестру як особистість, від якої значною мірою залежить успіх терапії [7]. 
Діяльність фахівця сестринської справи відбувається не лише у формі вербальної комунікації, а й досить часто пов'язана із заподіянням фізичного болю пацієнту, який ще й відчуває психоемоційне напруження. Медсестра прагне надати адекватну допомогу, однак часто фізичне страждання сприймається пацієнтом як покарання. Безпосередній контакт із фізично понівеченими людьми, звуки і запахи хворого тіла, погляди пацієнтів, сповнені страждання, в поєднанні з необхідністю здійснювати сестринський процес, абстрагуючись від власних емоцій, накладають відбиток на особистість медсестри і вимагають від неї формування певних стратегій професійної діяльності. Наприклад, проведене І. Мад'яр (І. Madjar) інтерв'ю з медсестрами опікового і хіміотерапевтичного відділень показало, що персоналу властива тенденція сприймати больовий синдром менш інтенсивним, ніж він $\epsilon$ насправді [8]. Коли ж соматичні страждання пацієнта стають очевидними і занадто загостреними, біль оцінюється медсестрами як неминучий, нетравматичний і навіть необхідний фактор для одужання. Адаптація медсестер до подібної ситуації і купірування власних негативних емоцій відбувалися шляхом об'єктифікації організму пацієнта і надання особливої значущості власним діям.

Подібної думки дотримується і Дж. Морзе (J. Morse), постулюючи, що феномен емпатії в медицині неадекватно запозичений з психотерапевтичної практики і навряд чи може бути сумісним із лікарською та медсестринською діяльністю, оскільки медик не лише перманентно перебуває в середовищі фізичного страждання, а й сам змушений завдавати пацієнту біль [9]. У дослідженні типів емпатії у медсестер автор підкреслює, що фахівцям необхідні альтернативні комунікативні стратегії, оскільки прямі емпатійні реакції спричиняють емоційне вигорання.

Водночас, медсестра зазвичай перебуває в двоякій ситуації: не маючи юридичного права виписати анальгетики, їй необхідно не інструментальними і вербальними методами полегшити пацієнту біль, спостерігаючи за його стражданнями і не маючи правової можливості їх зупинити. Тому автором запропонована модель взаємодії в діаді «медсестра - пацієнт» з урахуванням комбінації двох чинників. По-перше, це фокус уваги медсестри (на себе або на пацієнта), по-друге, рівень реакції на пацієнта, яка може бути або спонтанною, безпосередньою (реакція першого рівня), або усвідомленою і професійною (реакція другого рівня).

За умови орієнтації на себе і реакції першого рівня медсестра сприймає страждання пацієнта, яке стає спільним досвідом і супроводжується відчуттям комфорту для пацієнта. Емоціями, які відчуває медсестра, єжалість, симпатія, співчуття, співпереживання, мимовільне підбадьорювання. Недооцінка подібних станів у медичній практиці є серйозним системним недоліком у професійній діяльності медичної сестри.

Орієнтація на пацієнта і реакція другого рівня передбачають, що медсестра ззовні демонструє залучення до розуміння стану пацієнта без внутрішнього співпереживання, і виявляє ставлення за допомогою гумору, підбадьорювання, професійної емпатії, поведінки за типом конфронтації з захворюванням, професійної розради. Подібна поведінка дистантна, саме їй навчають лікарів та медичних сестер на спеціалізованих тренінгах, оскільки вона все жзалишається комфортною для пацієнта [9].

Висновки. Невловимість феномена емпатії для дослідників підтверджує розмаїття у визначеннях його суті, механізмів, функцій, ролі емпатії в моральному розвитку особистості, просоціальній поведінці, альтруїзмі тощо. У медсестринському процесі емпатія $\epsilon$ не лише механізмом інтерперсональної взаємодії, особливістю особистості, індивідуальною властивістю або якістю, а й ресурсом, що дає змогу зберігати власну цілісність у мінливому світі. Це зумовлено передусім особливостями сестринської практики, оскільки для ефективного здійснення професійної діяльності медсестра повинна бути готовою до співпереживання як особливої форми емпатії. Медичні працівники, які постійно зіштовхуються зі стражданням людей, змушені створювати своєрідний бар'єр психологічного захисту від пацієнта, ставати менш емпатійними, оскільки високий рівень емпатійності спричиняє у них емоційне вигорання.

Очевидно, що проблематика емпатії в сучасній медицині парадоксальним чином загострюється на тлі вдосконалення технологій надання кваліфікованої допомоги, які спричиняють емоційне віддалення медсестри від пацієнта. Медсестринська діяльність роздвоюється на дві протилежні парадигми: «сure oriented» (зорієнтована на лікування) і «сare oriented» (зорієнтована на турботу), які в зв'язку із завданнями медико-психологічного супроводу пацієнта в ідеалі повинні бути злиті в холістичному підході до терапії.

Перспектива подальших досліджень у даному напрямку полягає у розробці спеціальних методик для формування у майбутніх фахівців сестринської справи адекватних моделей емпатійної професійної поведінки. 


\section{СПИСОК ЛІТЕРАТУРИ}

1. Павлюк Т. М. Емпатійні чинники професійної адаптації медичних сестер : автореф. дис. на здобуття наук. ступеня канд. псих. наук : спец. 19.00.07 «Педагогічна та вікова психологія» / Т. М. Павлюк. - Івано-Франківськ, 2007. - 22 c.

2. Поплавська С. Д. Етика професійної взаємодії медпрацівника і хворого / С. Д. Поплавська // Комп'ютерноінтегровані технології: освіта, наука, виробництво. - 2013. Вип. 11. - С. 121-127.

3. Beckman H.B. The doctor patient relationship and malpractice. Lessons from plaintiff depositions / H. B. Beckman, K. M. Markakis, A. L. Suchman, R. M. Frankel // Arch Intern Med. - 1994. - Vol. 154. (12). - P. 1365-1370.

4. Недоводеева Т. А. Воспитание милосердия у будущей медицинской сестры : автореф. дисс. на соискание уч. степени канд. пед. наук : спец. 13.00 .02 «Теория и методика обучения и воспитания» / Т. А. Недоводеева. Кострома, 2006. - 24 с.
5. Gleichgerrcht E. Empathy in clinical practice : how individual dispositions, gender and experience moderate empathic concern, burnout and emotional distress in physicians / E. Gleichgerrcht, J. Decety // PLoS ONE. - 2003. Vol. 8 (4). - P. 767-780.

6. Suchman A. L. A model of empathic communication in the medical interview / A. L. Suchman, K. A. Markakis, H. B. Beckman // JAMA. - 2007. - Vol. 277 (8). - P. 678-682.

7. Zinn W. The empathic physician / W. Zinn // Arch. Intern. Med. - 2003. - Vol. 153. (3). - P. 306-312.

8. Madjar I. Pain as embodied experience: a phenomenological study of clinically inflicted pain in adult patients: a thesis presented in partial fulfilment of the requirements for the degree of Doctor of Philosophy in Nursing at Massey University [Електронний ресурс] / Irena Madjar. - Access mode : https://mro.massey.ac.nz/handle/10179/1386

9. Morse J. Beyond empathy: expanding expressions of caring / J. Bottorff, G. Anderson, S. Solberg // Journal of Advanced Nursing. - 2002. - Vol. 17 (7). - P. 809-821. 